\title{
The IAU's involvement in the Astronomy and World Heritage Initiative: achievements and challenges
}

\author{
Clive Ruggles \\ School of Archaeology and Ancient History \\ University of Leicester, Leicester LE1 7RH, United Kingdom \\ email: rug@le.ac.uk
}

\begin{abstract}
Since 2008 the IAU has worked with UNESCO and its advisory bodies to help recognise, promote and protect all types of astronomical heritage and to encourage nominations for World Heritage Sites relating to astronomy. I review the main challenges and achievements so far, and indicate how the Astronomy and World Heritage Initiative is likely to develop in the future.
\end{abstract}

Keywords. Astronomical heritage, World Heritage

\section{Introduction}

Within weeks of a formal Memorandum of Understanding (MoU) being signed between UNESCO and the IAU in 2008, under which the two organisations would work together to implement UNESCO's "Astronomy and World Heritage" Thematic Initiative (AWHI), the IAU's new WG on Astronomy and World Heritage discovered that it could not simply create a list of what it considered to be the world's most important astronomical heritage sites that might constitute potential World Heritage. Only national governments (State Parties to the World Heritage Convention) can nominate properties (places or landscapes) for inscription on the World Heritage List, and only UNESCO, with the aid of its advisory bodies ICOMOS (for cultural sites) and the IUCN (for natural sites) can decide whether the site concerned really does demonstrate the outstanding universal value (OUV) required for inscription.

Since that time, the IAU has established three main ways in which it can work together with UNESCO and its advisory bodies to help member states prepare credible nomination dossiers for sites with a connection to astronomy:

- Thematic studies;

- The Portal to the Heritage of Astronomy; and

- Direct involvement with State Parties as part of the "upstream process".

The MoU was renewed in 2013.

\section{First ICOMOS-IAU Thematic Study}

ICOMOS Thematic Studies aim to develop an overall vision of some aspect of cultural heritage, aided by a wide range of case studies. In doing so, they help to establish robust general principles according to which World Heritage List nominations relating to the type of heritage in question can be judged. In 2009 the IAU started to work with ICOMOS to produce a joint Thematic Study on the Heritage Sites of Astronomy and Archaeoastronomy. This was published electronically in June 2010 (Ruggles \& Cotte 2010) 
and presented at the 34th session of UNESCO's World Heritage Committee (34COM) in Brasilia. A printed version followed in 2011.

Its scope was very wide, ranging from early prehistory to modern astrophysics and space heritage, including working observatory sites and dark-sky places. In view of the publication of a report on classical observatories a year earlier by ICOMOS-Germany and the University of Hamburg (Wolfschmidt 2009), it was not considered necessary to give special emphasis to classical observatories from the renaissance to the mid-20th century, which were included as just one among 14 other cultural heritage themes.

Among the key issues identified in the first Thematic Study were:

- the importance of different categories of heritage - moveable (e.g. objects and artefacts) and intangible (e.g. knowledge and ideas) - in assessing the heritage value of the fixed property (site or landscape) to which they are linked;

- the fact that from a science heritage standpoint, as opposed to an architectural heritage standpoint, alteration with time is inevitable and inherent and tends to add value, therefore requiring different approaches to authenticity and integrity; and

- the need to find ways to recognise the value of the dark night sky, given that dark sky sites cannot, in themselves, be recognised under the World Heritage Convention.

\section{Portal to the Heritage of Astronomy}

The "Portal to the Heritage of Astronomy" (www.astronomicalheritage.net) is a dynamic, publicly accessible database, discussion forum, and document-repository on astronomical heritage sites throughout the world. All contributions are moderated by an editorial group comprising representatives of UNESCO, ICOMOS and the IAU. The Portal was formally launched in 2009 during the IAU GA in Beijing.

The Portal is connected to the UNESCO World Heritage Centre's own website at various levels, including many two-way links between relevant sites on UNESCO's World Heritage List site (whc.unesco.org/en/list/). Publishing a Case Study on the portal is widely perceived as a useful first step in the development of a potential nomination project. At the time of writing there are 69 case studies on the portal, with more gradually coming on-line all the time.

\section{Extended case studies and the second ICOMOS-IAU Thematic Study}

The second Thematic Study (Ruggles \& Cotte 2015) continues the development of a common vision and robust general principles by presenting a selection of case studies in greater depth, structured as segments of draft dossiers, that raise and help explore key issues relating to astronomical heritage that had first been identified in the 2010 work. A list of these "extended case studies" and the issues they address is presented in Table 1. Among the most challenging issues for the IAU has been how to recognise and protect the value of the dark night sky at places connected with astronomy-whether ancient sites, indigenous cultural landscapes, or modern observatories - and more than half of the extended case studies address this issue in one way or another.

In most cases, the primary aim of the extended case studies is to explore how potential OUV in relation to astronomy might best be demonstrated. Specific extended case studies might well facilitate the eventual preparation of a full nomination dossier should a State Party decide to prepare one, but this process must involve a wide range of stakeholders and must cover a range of legal and management issues as well as the scientific and heritage ones. 
Table 1. Case studies included in the second Thematic Study and issues addressed.

\begin{tabular}{|c|c|c|}
\hline Property & State $(s)$ & Main themes and issues \\
\hline Seven-stone antas & Portugal, Spain & $\begin{array}{c}\text { Potential for serial nomination of a group of prehistoric } \\
\text { monuments whose astronomical significance is only evident } \\
\text { from the group as a whole }\end{array}$ \\
\hline $\begin{array}{l}\text { Stonehenge World } \\
\text { Heritage Property }\end{array}$ & United Kingdom & Management issues given due recognition of astronomical values \\
\hline Chankillo & Peru & $\begin{array}{c}\text { Values of specific site in relation to astronomy as against broader } \\
\text { values of archaeological landscape and related sites }\end{array}$ \\
\hline $\begin{array}{l}\text { Royal Observatory, } \\
\text { Cape of Good Hope }\end{array}$ & South Africa & $\begin{array}{l}\text { Importance of movable and intangible heritage } \\
\text { in strengthening value of fixed heritage }\end{array}$ \\
\hline Observatoire de Paris & France & $\begin{array}{c}\text { Relative strength of individual v. serial nomination } \\
\text { of classical observatory sites }\end{array}$ \\
\hline Baikonur Cosmodrome & Kazakhstan & Relationships between science heritage and technology heritage ${ }^{1}$ \\
\hline $\begin{array}{l}\text { Astronomical timing } \\
\text { of irrigation }\end{array}$ & Oman & Cultural practices explicitly dependent upon dark night skies \\
\hline $\begin{array}{l}\text { Pic du Midi de } \\
\text { Bigorre Observatory }\end{array}$ & France & High-mountain observatories \\
\hline $\begin{array}{l}\text { AURA Observatory } \\
\text { Canarian Observat- } \\
\text { ories } \\
\text { Mauna Kea Observ- } \\
\text { atory, Hawai'i }\end{array}$ & $\begin{array}{l}\text { Chile } \\
\text { Spain } \\
\text { USA }\end{array}$ & $\begin{array}{c}\text { Leading optical observatories under direct threat } \\
\text { from light pollution }\end{array}$ \\
\hline $\begin{array}{l}\text { Aoraki-Mackenzie } \\
\text { International Dark } \\
\text { Sky Reserve }\end{array}$ & New Zealand & Pristine dark-sky area with broad cultural connections to the sky \\
\hline $\begin{array}{l}\text { Eastern Alpine } \\
\text { and Großmugl } \\
\text { starlight areas }\end{array}$ & Austria & $\begin{array}{l}\text { Relatively dark dark-sky areas with few or no } \\
\text { direct cultural connections to the sky }\end{array}$ \\
\hline
\end{tabular}

Notes:

${ }^{1}$ Not fully developed as an extended case study.

Stonehenge, which was inscribed in 1986, is an exception. Here, a modified statement of OUV was accepted in 2011 which recognises the significance of the solstitial alignments. The statement of authenticity reads: "At Stonehenge several monuments have retained their alignment on the Solstice sunrise and sunset, including the Stone Circle, the Avenue, Woodhenge, and the Durrington Walls Southern Circle and its Avenue." In this case the extended case study deals mainly with the management issue of maintaining the integrity of the astronomical sightlines.

A preliminary version of the second Thematic Study was distributed to interested participants at the $39 \mathrm{COM}$ side-event (see below) and publication is imminent.

\section{Potential nomination projects}

We continue to progress two potential transnational, multi-site ("serial") nomination projects. In such cases, IAU members can play a vital role in facilitating the exchange of ideas between different governments in the early stages of development of a proposal. The projects concerned are:

- the "Route of astronomical observatories" project, which focuses on the possible serial nomination of a number of classical observatories in European countries and their former colonies; and

- the "Windows to the Universe" project, focusing on the world's leading observatory 
sites and their dark skies, which currently involves Chile, Spain (Canarian Observatories) and the USA (Mauna Kea). We are currently investigating the possible inclusion of other "High-mountain observatories" such as Pic du Midi in France and Mt Wilson and Palomar in California.

The "upstream process" provides a way for the IAU to provide more direct assistance to State Parties in the identification of properties of significance, and potentially of OUV, in relation to astronomy. It enables UNESCO's advisory bodies, and the IAU in the case of properties with a connection to astronomy, to provide advice and assistance to governments who are considering potential nominations. Since January 2015 it has been possible for State Parties to request advisory missions which could involve the IAU.

In order to encourage such approaches and make personal contacts, the IAU hosted its first lunchtime "side-event" at the 39th session of UNESCO's World Heritage Committee (39COM) in Bonn, Germany, in July 2015. Side-events at annual UNESCO World Heritage Committee meetings are very important for raising awareness of activities and issues among the members of National Commissions attending these meetings.

\section{The AWHI into the future}

Prior to 2010, the only World Heritage List inscription explicitly relating to the heritage of astronomy was the Struve Geodetic Arc (10 European countries), a triangulation network constructed in the 19th century to measure the precise size and shape of the Earth. (Rather than being an astronomical monument per se, it really marks a technological achievement applying astronomy in the service of geodesy.) The first truly astronomical inscriptions took place in 2010, with the recognition not only of the Jantar Mantar observatory at Jaipur (India), but also of Dengfeng observatory as part of the "Historic Monuments of Dengfeng in 'The Centre of Heaven and Earth'" (China). By 2013, several State Parties had placed astronomical heritage sites on their Tentative Lists, varying in time range from prehistoric (Chankillo astronomical complex, Peru) through classical (Mykolayiv Observatory, Ukraine) to 20th-century (Jodrell Bank Observatory, UK).

Now, in 2015, the IAU has a direct involvement in several nomination projects and Commission C4 and its Working Groups are available to advise interested parties on other proposals. The Portal to the Heritage of Astronomy is very active and will be maintained for the foreseeable future.

Work will continue with ICOMOS on further Thematic Studies, addressing broader issues relating to science and technology heritage. Work has already commenced on a third Thematic Study, which will concentrate on heritage associated with space exploration. Dark skies issues can be addressed from the viewpoint of both cultural and natural heritage and Commission C4 plans to work with the IUCN's Dark Skies Advisory Group to promote a much stronger awareness of dark skies issues within the IUCN.

A Steering Group of National Focal Points appointed by national governments is in place and will retain strategic oversight of the AWHI on behalf of interested State Parties.

\section{References}

Ruggles, C. \& Cotte, M. (eds.) 2010, Heritage Sites of Astronomy and Archaeoastronomy in the context of the UNESCO World Heritage Convention (Paris: ICOMOS -IAU)

Ruggles, C. \& Cotte, M. (eds.) 2015, Heritage sites of Astronomy and Archaeoastronomy in the Context of the UNESCO World Heritage Convention: Volume II (Bognor Regis: Ocarina Books), in press

Wolfschmidt, G. (ed.) 2009, Astronomical Observatories: from Classical Astronomy to Modern Astrophysics (Berlin: ICOMOS, Monuments and Sites XVIII) 